\title{
Quality of beef burger with addition of wet okara along the storage
}

\author{
Qualidade de hambúrguer bovino com adição de okara úmida \\ ao longo do armazenamento
}

\author{
Rafaela Bergmann Strada de Oliveira ${ }^{1 *}$, Flávia Della Lucia², Eric Batista Ferreira², \\ Roseane Maria Evangelista de Oliveira ${ }^{3}$, Carlos José Pimenta ${ }^{3}$, Maria Emília de Sousa Gomes Pimenta ${ }^{3}$
}

\author{
'Universidade José do Rosário Vellano/UNIFENAS, Alfenas, MG, Brasil \\ 2Universidade Federal de Alfenas/UNIFAL, Alfenas, MG, Brasil \\ ${ }^{3}$ Universidade Federal de Lavras/UFLA, Departamento de Ciência dos Alimentos/DCA, Lavras, MG, Brasil \\ *Corresponding author: rafaela.bergmann@unifenas.br \\ Received in February 19, 2016 and approved in September 12, 2016
}

\begin{abstract}
Combining the consuming of agricultural residues with satisfying consumers is a challenge that may result in financial income for the frozen meat industries, besides generating products with different nutritional value and satisfactory technological quality. Thus, we aimed at elaborating and assessing the physical, chemical and microbiological characteristics of frozen raw and fried beef hamburgers with addition of okara in its wet form throughout their storage over a period of 120 days. The inclusion of okara was proportional to the reduction in the content of protein, and to the increase of the lipid and moisture amount in the fried and raw formulations. Okara increased the luminosity and dimmed along the storage period. In the raw formulations at zero time lower values for $b^{*}$, $a^{*}$ were observed when compared to the zero time of the fried hamburgers. This leaded to a light brown color and highlighting the clearing of the color due to the inclusion of okara. The fried hamburgers also featured this clearing, but they were darker brown. Chromaticity was greater with the inclusion of okara and with the passage of time. It can be concluded after 120 days storage the levels of protein, lipid and moisture of the formulations were according to the recommended by the Technical Regulation for Identity and Quality of Hamburgers and comply with the requirements of the Brazilian Law for microbiological standards. The brown colour changed with the inclusion of okara but without alterations in the characteristic colour for beef burguers.
\end{abstract}

Index terms: Soybean; residues; hamburgers; technological characteristics.

\section{RESUMO}

Aliar o consumo de resíduos agrícolas e satisfazer o consumidor é um desafio que pode resultar em aporte financeiro para as indústrias de alimentos cárneos congelados, além de originar produtos com valor nutricional diferenciado e qualidade tecnológica satisfatória. Sendo assim objetivou-se elaborar e avaliar as características físicas, químicas e microbiológicas de hambúrgueres congelados crus e fritos de carne bovina com adição de okara em sua forma úmida ao longo do seu armazenamento em congelamento por um período de 120 dias. Observouse que a inclusão de okara foi proporcional a diminuição do teor proteínas, ao aumento dos teores de lipídeos e umidade das formulações cruas e fritas e que após os 120 dias de armazenamento as formulações atendiam o preconizado pelo Regulamento Técnico de Identidade e Qualidade de Hambúrgueres. A inclusão de okara aumentou a luminosidade dos hambúrgueres e foi diminuindo com o passar dos dias de armazenamento, exceto nas formulações com 5 e $10 \%$ fritas. Para as formulações cruas no tempo zero observam-se menores valores de b*, a* quando comparados ao tempo zero dos hambúrgueres fritos, o que leva uma coloração marrom clara e indicando o clareamento na cor com o aumento da inclusão de okara. Os hambúrgueres fritos também possuem esta indicação, porém apresentaram-se marrom mais escuro. A cromaticidade foi maior conforme a inclusão de okara e o passar do tempo. Conclui-se que após 120 dias de armazenamento os hambúrgueres atendiam o preconizado pelo Regulamento Técnico de Identidade e Qualidade de Hambúrgueres no que diz respeito aos teores de proteínas, lipídeos e umidade e que atendiam a legislação do ponto de vista microbiológico. A coloração marrom dos produtos modificou-se com a inclusão de okara sem, no entanto alterar a coloração característica de hambúrgueres.

Termos para indexação: Soja; resíduos; hambúrgueres; características tecnológicas.

\section{INTRODUCTION}

Alternative low cost foods, such as residues and agricultural byproducts, represent a way of minimizing the expenses on food. The residues and agricultural byproducts may present markets already defined, representing significant financial income to the agriculture industry (Oliveira et al., 2008).

Presently, consumers are becoming more demanding as to the quality of foods, and they expect this to be maintained in the period between the purchase and the final consumption. These expectations are consequence 
not only of the demand for safe products, but also of the necessity to minimize unwanted alterations in their qualities. Combining the consume of residues with satisfying the consumers is a challenge that may result in financial income to the industries of frozen meat foods besides originating products with differentiated nutritional values and satisfactory technological quality. Freezing is very used in modern life in order to increase the shelflife of products, which should guarantee their absolute preservation for a long time.

Soybean is a plant belonging to the Leguminosae (Fabaceae) family, and the cultivated soybean is classified as Glycine max (L.) Merril (Gesinde; Oyawoye; Adebisi, 2008). The economic importance of soybean is due to its high nutritional value (Aplevicz; Demiate, 2007). Epidemiological studies demonstrate that the consume of vegetables is associated to the reduction of the risk of chronic diseases (Jimenez-Escrig; Serra; Rupérez, 2010) and the use of soybean has increased because of the importance of the nutritional properties and the functional characteristic of its bioactive components, which are implicated in the prevention of chronic diseases (Ribeiro et al., 2007). With the intention of providing the organism with the nutrients existing in soybean, there are several products derived from this leguminous, which generate foods with higher protein content, reducing costs and increasing consumers' acceptance related to soybean products (Mateos-Aparicio; Redondo-Cuenca; VillanuevaSuárez, 2010).

Okara is the residue of the production of the aqueous extract of soy and is considered a byproduct presenting low market value because it consists of about $80 \%$ water, becoming voluminous, difficult to manipulate and highly susceptible to microbial deterioration (Perussello; Amarante; Mariani, 2009). Okara is also rich in fibers and proteins (Sengupta et al., 2012). Its utilization, besides increasing the nutritional quality of food products and adding value to them, reduces the waste of foods and minimizes the generation of industrial residues (Tie Su et al., 2013).

One option for the utilization of okara would be to include it in the formulation of hamburgers, products with high consume by the Brazilian and the world's population. The national consume of frozen hamburgers is higher in volume than the majority of other frozen meat products (Nascimento; Oliveira; Nascimento, 2005). Hamburgers have become a product consumed by all popular classes as result of the practicality of their preparation, and for containing nutrients that feed and satiate hunger fast. Due to the acceleration of the urban rhythm caused by the productionist schedulle, the search for industrialized products easy to prepare is more and more evident (Oliveira et al., 2013). Hamburgers are industrialized products made with ground meat, with or without tissue, with addition of fat tissue and other ingredients or not, shaped and submmited to a suitable technological process (Brasil, 2000). Industries of processed meats must provide a great variety of products to consumers, mainly with affordable prices, in order to increase their consume (Soltanizadeh; Ghiasi-Esfahani, 2015) and they should try to reduce the costs of their formulations without compromising the quality (Akwetey; Knipe, 2012). The inclusion of residues would be an alternative. The present study aimed at elaborating and evaluating the physical, chemical and microbiological properties of frozen raw and fried hamburgers made of beef with addition of okara in its wet form, during their frozen storage period of 120 days.

\section{MATERIALS AND METHODS}

\section{Raw material}

Soybean was obtained in grains $\left(\right.$ Natudday $\left.^{\circledR}\right)$ from the same batch. The topside cut beef $\left(\mathrm{JBS}^{\circledR}\right)$ and the rest of the ingredients (garlic and salt seasoning (Arisco ${ }^{\circledR}$ ), soybean oil $\left(\right.$ Soya $\left.^{\circledR}\right)$, ground black pepper $\left(\right.$ Hikari $\left.^{\circledR}\right)$ were gotten from the local market (Alfenas, MG Brazil).

\section{Okara processing}

1 litre of water was heated at $98{ }^{\circ} \mathrm{C}, 200 \mathrm{~g}$ of soybean were added waiting for the mixture to reach the temperature of $98{ }^{\circ} \mathrm{C}$ and submitted at this temperature for 5 minutes. Afterwards, the water was despised and a thermal shock was realized for 5 minutes in a bowl with ice. The soybean grains were ground in a blender (Walita ${ }^{\circledR}$ ) with the addition of 500 $\mathrm{mL}$ of water for approximately 2 minutes. This content was boiled in a 1.5 litre of water at $98{ }^{\circ} \mathrm{C} / 10$ minutes and finally filtered in an organza tissue. The filtered solution (soybean aqueous extract) was despised and the resulting residue was the humid okara utilized. After processing, the humid okara was immediately refrigerated $\left(7^{\circ} \mathrm{C}\right)$, and in the same day was used to prepare the formulations.

\section{Hamburger formulations}

After the purchase of cooled and vacuum-sealed beef, the cleaning with the separation of apparent nerves and fats was carried out. The beef was cut in pieces of 
approximately $100 \mathrm{~g}$ each, and ground in a disk of $5 \mathrm{~mm}$ in a grinding machine (C.A.F ${ }^{\circledR}$, model $22 \mathrm{STB}$ ). The beef burgers were processed following proper manufacturing procedures, they were mixed up in a bowl and molded in plastic molds for hamburgers. The formulations are displayed in Table 1. The beef burgers were frozen at $-18{ }^{\circ} \mathrm{C}$ until the start of analysis.

\section{Thermal treatment}

After the thawing at $4{ }^{\circ} \mathrm{C}$ for 12 hours, the beef burgers were prepared, grilled in a saucepan with $2 \mathrm{~mL}$ of soybean oil per unit, kept there for 5 minutes on each side (totally 10 minutes) over a medium flame $\left(200^{\circ} \mathrm{C}\right)$. The internal temperature was controlled with a digital thermometer to guarantee the minimal internal temperature of $74^{\circ} \mathrm{C}$.

\section{Microbiological Analyses}

All the analyses were carried out in triplicate and followed the methodologies indicated by Silva, Junqueira and Silveira (2007): total count of mesophilic aerobic microorganisms, filamentous fungi and yeasts, coliforms at $35{ }^{\circ} \mathrm{C}$ and $45{ }^{\circ} \mathrm{C}$ by the Most probable number method, positive coagulase Staphylococcus, Salmonella sp., sulphite-reducing Clostridium at $46{ }^{\circ} \mathrm{C}$ and Bacillus cereus.

\section{Proximate Composition Analysis}

Moisture, lipid and crude protein analyses were performed using the methods proposed by AOAC (2005).

\section{Physical Analyses}

The colour was determined by a Konica Minolta $^{\circledR}$ CR 400 colorimeter in the CIE mode for the reading of $\mathrm{L}^{*}$ (luminosity, $100=$ white, $0=$ black), $\mathrm{a}^{*}$ (red/green intensity) and $\mathrm{b}^{*}$ (yellow/blue intensity) parameters under the following conditions: D65 illuminant source, angle of view of $8^{\circ}$, standard angle of the observer of $10^{\circ}$ (Commission Internationale de $\mathrm{L}^{\prime}$ Éclairage). The Hue angle $\left(h^{0}\right), \mathrm{a}^{*}$ and $\mathrm{b}^{*}$ values were converted in accordance with the Equation: $h^{0}=\tan ^{-1}$ $\left(b^{*} / a^{*}\right)$ and the saturation calculation (Chromaticity) in accordance with the Equation $\mathrm{C}=\sqrt{(}\left(\mathrm{a}^{*}\right)^{2}+\left(\mathrm{b}^{*}\right)^{2}$. For the visualization of the colouring corresponding to the coordinates $\mathrm{L}^{*}, \mathrm{a}^{*}$ and $\mathrm{b}^{*}$, a 3D diagram of dispersion was constructed, whose colouring of each treatment is represented with a point in accordance with the transformation for the RGB system (red-green-blue) of colours. For this reason the R software was used ( R Core Team, 2015) by functions of the plot3D package (Soetaert, 2014).

The texture instrumental analysis was realized by the TA.XT plus texturometer (Texture Technologies corp./ stable micro systems, UK), equipped with the Warner-Bratzler $(W B)$ device with a measure of force under compression. The equipment was calibrated with a standard weight of $5 \mathrm{Kg}$ and with a traceable standard (speed: $2 \mathrm{~mm} / \mathrm{s}$ during the pre-test phase, $10 \mathrm{~mm} / \mathrm{s}$ during the test and the post-test phase). The peak of the force necessary to cut the samples was expressed in kgf.

\section{Statistical analysis}

The experiment was conducted with a completely randomized experimental design and subdivided parcels in time $(6 \times 5)$, being 6 levels of okara inclusion $(0 \%$ control, $5 \%, 10 \%, 15 \%, 20 \%$ and $25 \%$ ) and 5 storage times $(0,30,60,90$ and 120 days). The data obtained were subjected to analysis of variance followed by an adjustment of the regression models and/or Tukey's test at 0.05 significance. The statistical analysis was performed with the R software (R Core Team, 2015), and with the ExpDes packet (Ferreira; Cavalcanti; Nogueira, 2014).

Table 1: Composition of formulations of beef burgers with wet okara in different concentrations.

\begin{tabular}{ccccccc}
\hline & \multicolumn{7}{c}{ Formulations (\%okara) } \\
\hline Ingredients (g) & F0 & F1 & F2 & F3 & F4 & F5 \\
\hline Minced meat & 100 & 95 & 90 & 85 & 80 & 75 \\
Wet okara & 0 & 5 & 10 & 15 & 20 & 25 \\
Seasoning salt and Garlic & 2.3 & 2.18 & 2.07 & 1.95 & 1.84 & 1.72 \\
Ground black pepper & 0.3 & 0.28 & 0.27 & 0.25 & 0.24 & 0.22 \\
\hline
\end{tabular}

$\mathrm{F} 0=0 \%$. $\mathrm{F} 1=5 \%$. F2 $=10 \%$. F3=15\%. F4= 20\%. F5 $=25 \%$. 


\section{RESULTS AND DISCUSSION}

\section{Microbiological analyses}

There was no increase in any microbiological parameter performed throughout the storage period, either in the raw formulations or in the fried ones. The hamburger formulations made with addition of okara comply with the requirements of the Brazilian Law $\mathrm{RDC} \mathrm{n}^{\circ} 12,2001$, which regulates (Brasil, 2001) the microbiological standards.

\section{Proximate composition analyses}

There was no change in the percentage of protein (Figure 1A) in the raw hamburgers up to 30 days in storage. Only on the $120^{\text {th }}$ day, F2 presented lower content of protein than at time 0 . It is emphasized that F1, F4 and F5
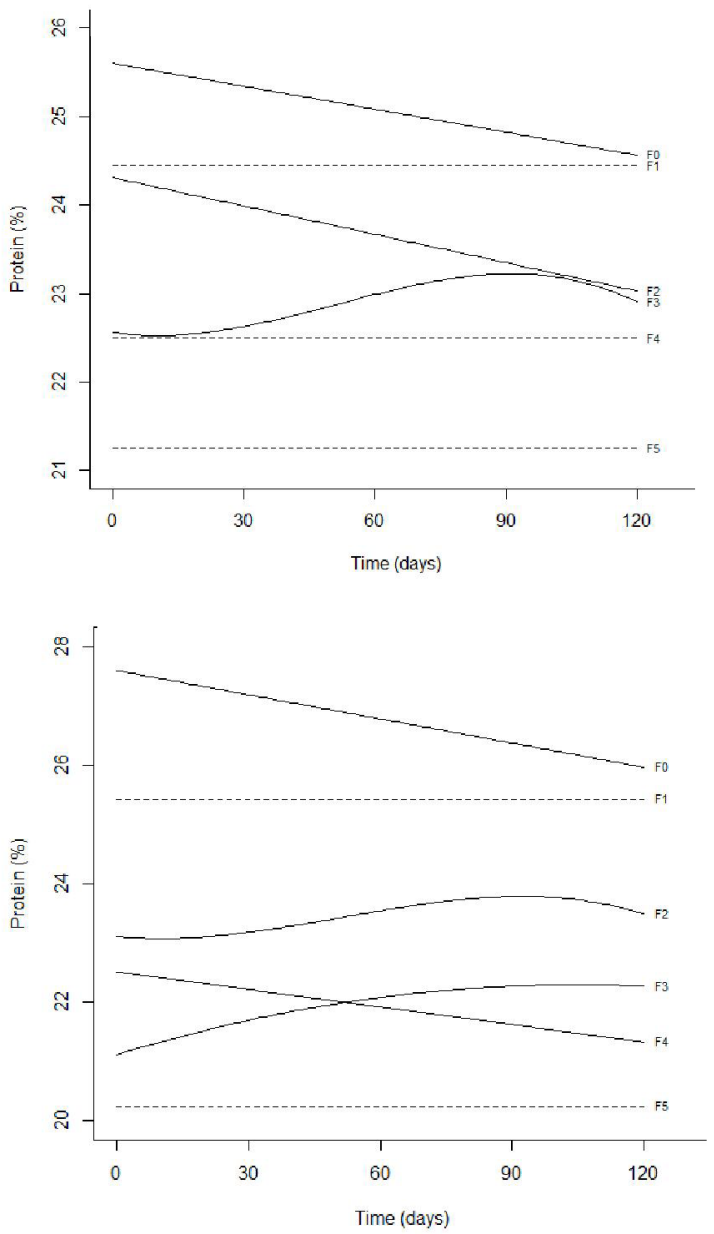

Figure 1: Means observed and regression model adjusted for protein values (\%) of raw (A) and fried (B) beef hamburgers with addition of different concentrations of wet okara along the storage period in days. F0- control; F1- 5\%; F2- 10\%; F3- 15\%; F4- 20\%; F5- 25\%. did not present differences at any of the analyzed times, maintaining the same protein level during the storage period.

In the fried formulations, it is possible to observe that F1 and F5 did not show significant differences during the storage period. However, F0 presented a minimal drop, yet gradual, in the percentage of protein from the $30^{\text {th }}$ day on. F2 showed a slight variation in the protein levels during the storage time, presenting time 0 and the $120^{\text {th }}$ day with values statistically equal. F3 was different from each other at the beginning and at the end of the experiment with values varying between 21.30 (day 0$)$ and $22.18\left(120^{\text {th }}\right.$ day), respectively. F4 obtained similar values at time 0 and on the $30^{\text {th }}$ day, decreasing the protein value along the storage period, with days 60, 90 and 120 statistically equal (Figure 1B). It is observed that, either in the raw formulations or in the

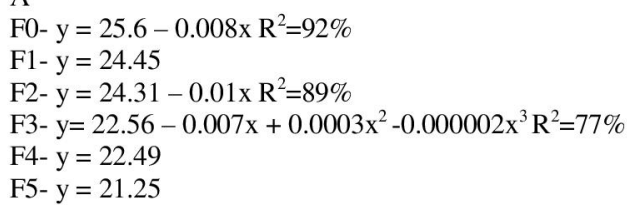


fried ones, as the content of okara was increased, the content of protein decreased. It is believed that freezing may have led to decreased protein activity, being able to prevent the growth of large ice crystals and then delaying protein denaturation. A similar result was observed in frozen of pork meat by Pires et al. (2002). Provesi and Amante (2015) emphasize that when large ice crystals are formed could be occur damage into the integrity of cellular components, significantly altering the original characteristics of the food. The reduction in the protein content was expected, since beef is a high protein food and its subtraction would result similar, but not enough to adversely influence to the formulations in compliance with the legislation.
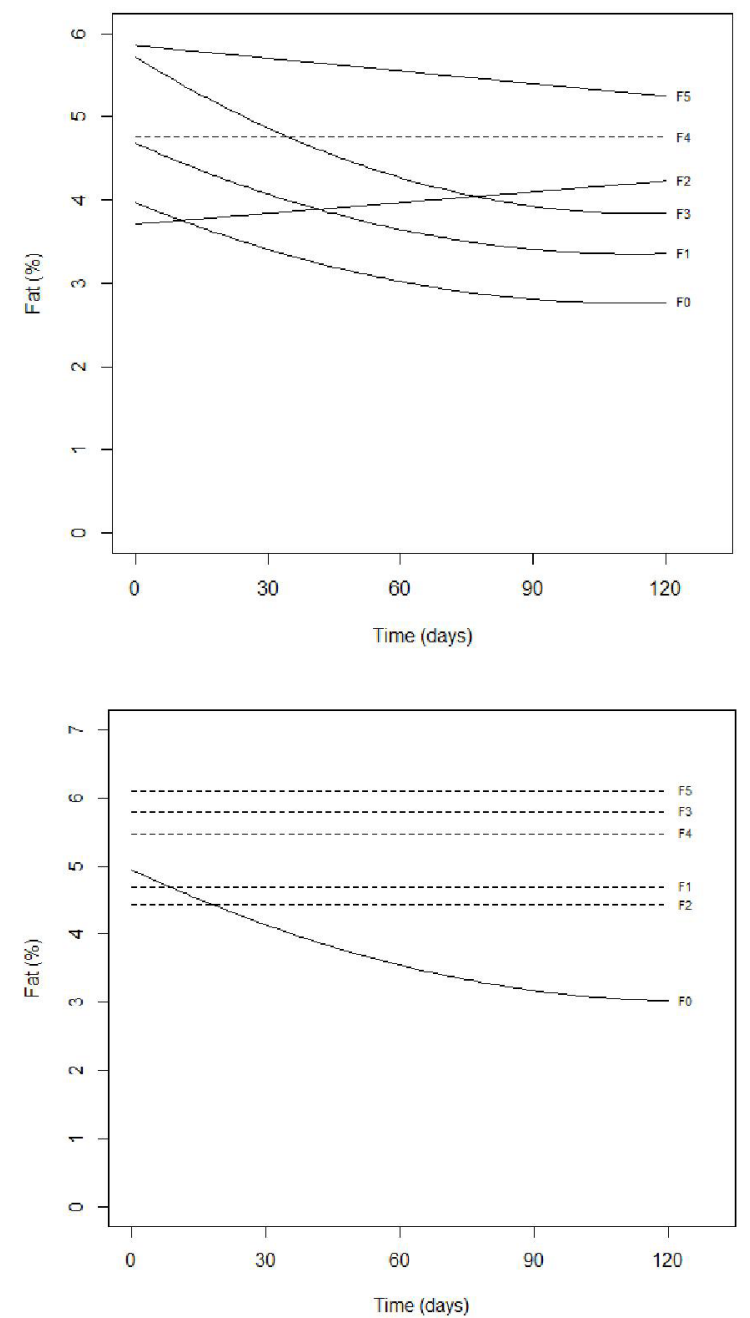

Concerning the amount of lipids in the raw formulations (Figure 2A) it is noted that $\mathrm{F} 4$ has maintained itself constant during the storage period. F0, F1 and F3 have kept equable up to the $30^{\text {th }}$ day of storage, decreasing these values from the $60^{\text {th }}$ day on, but they were statistically uniform on the $90^{\text {th }}$ and on the $120^{\text {th }}$ day. F2 has shown statistically even values for time 0 and the $120^{\text {th }}$ day, with the $30^{\text {th }}$ day equal to time 0 and different from the rest. F5 presented even lipid values from day 30 on, with only time 0 equal to the $30^{\text {th }}$ day.

Significant diferences may be observed in the fried formulations just in F0, with reduction in lipid percentage from day 30 on.
A

$$
\begin{aligned}
& \text { F0- } y=3,97-0,02 x+0,00009 x^{2} R^{2}=89 \% \\
& \text { F1- } y=4,68-0,02 x+0,0002 x^{2} R^{2}=89 \% \\
& \text { F2- } y=3,71+0,004 x R^{2}=57 \% \\
& \text { F3- } y=5,71-0,03 x+0,0001 x^{2} R^{2}=86 \% \\
& \text { F4- } y=4,75 \\
& \text { F5- } y=5,85-0,005 x R^{2}=82 \%
\end{aligned}
$$

\section{B}

$$
\begin{aligned}
& \text { F0- } y=4,94-0,03 x+0,0001 x^{2} R^{2}=82 \% \\
& \text { F1- } y=4,69 \\
& \text { F2- } y=4,42 \\
& \text { F3- } y=5,79 \\
& \text { F4- } y=5,47 \\
& \text { F5- } y=6,10
\end{aligned}
$$

Figure 2: Means observed and regression model adjusted to values of lipids (\%) in formulations of raw (A) and fried (B) beef hamburger with addition of different concentrations of humid okara throughout the storage period in days. F0- control; F1-5\%; F2-10\%; F3-15\%; F4-20\%; F5-25\%. 
It is noticed that either in the raw formulations or the fried ones, as the percentage of okara increases, an increase of the content of lipids occurs. In studies with addition of okara in French-type breads, Bowles and Demiate (2006) found increasingly lipid values in accordance for the inclusion of okara. These results corroborates the results obtained in our study, even with different raw materials, suggesting that okara may increase lipid value. Already Tie Su et al. (2013) working with hamburger found higher values of lipid to control the formulation with $20 \%$ okara and, emphasize that even with the percentage increase in the lipids content, the burgers could be labeled as a product with reduced lipid content comparing to the commercials.

Concerning moisture in the raw formulations (Figure 3A), it is possible to notice that it did not suffer
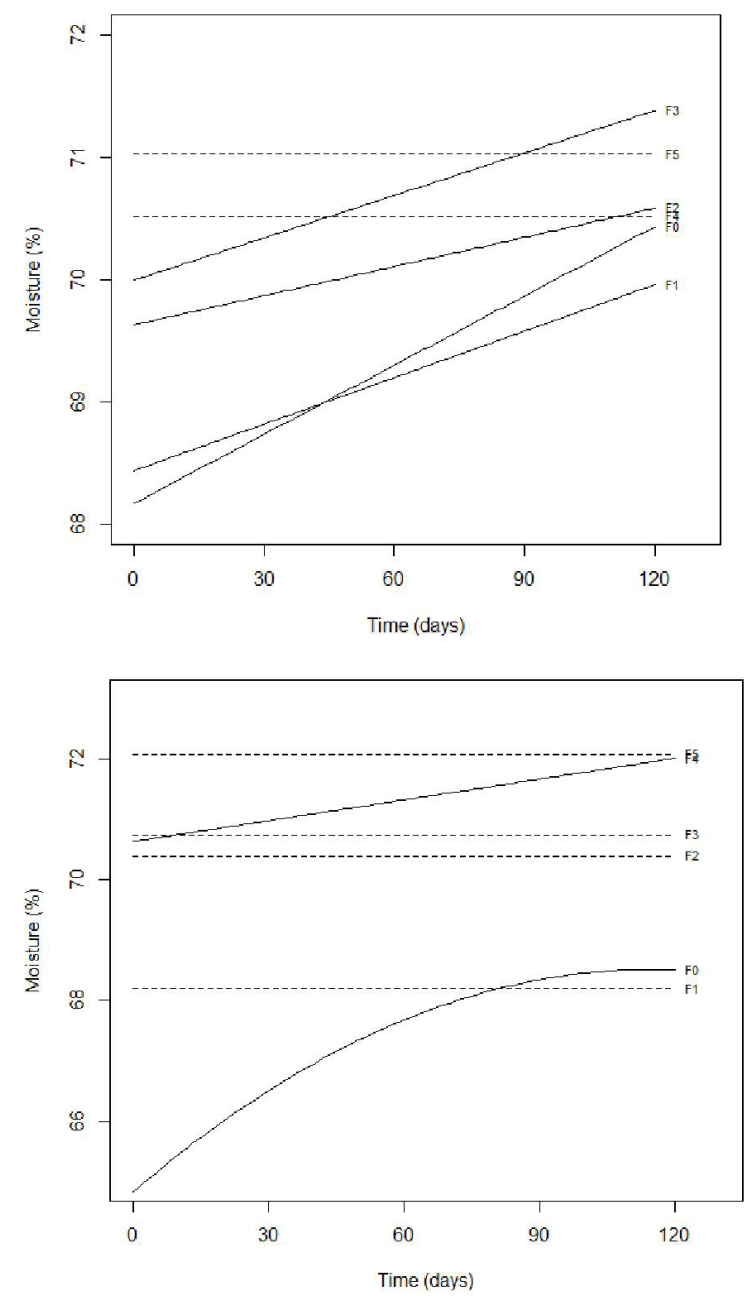

variations during the storage period in F4 and F5. F0, F1 and $\mathrm{F} 3$ presented increase in moisture, with moment 0 different from the $120^{\text {th }}$ day. In F2, a slight increase was perceived, with time 0 statistically identical to times 30 , 90 and 120 days, but different from day 60 .

In the fried formulations (Figure 3B), we noticed that F1, F2, F3 and F5 did not present differences along the storage period. F0 showed increase in moisture from day 30 on similarly to time 0 , but different from the other formulations. In F4, time 0 showed to be different from the $120^{\text {th }}$ day, when it was possible to observe higher values.

As wet okara was added to the formulations, an increase in the content of moisture was observed in the raw and fried formulations.
A

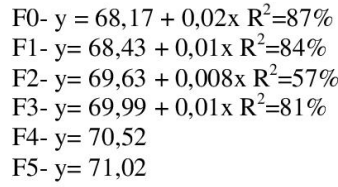

B Fo- $y=64,82+0,06 x-0,0002 x^{2} R^{2}=86 \%$

$\mathrm{F} 1-\mathrm{y}=68,20$

F2- $y=70,40$

F3- $y=70,75$

F4- $y=70,64+0,01 \times R^{2}=87 \%$

F5- $y=72,09$

Figure 3: Means observed and regression model adjusted to values of lipids (\%) in formulations of raw (A) and fried (B) beef hamburger with addition of different concentrations of wet okara throughout the storage period in days. F0- control; F1- 5\%; F2-10\%; F3-15\%; F4-20\%; F5-25\%. 
When comparing with other studies that have used okara in the formulation of hamburgers, it is possible to observe a variation in the chemical composition, probably due to the nature of the used raw materials. Turhan, Temiz and Sagir (2009) found results of $58.89 \%$ moisture, $20.43 \%$ protein and $14.01 \%$ of lipids in formulations of raw hamburger with addition of $10 \%$ of okara in powder. In the grilled hamburgers with the same formulation the results were: $49.12 \%$ moisture, $24.31 \%$ de protein and $15.57 \%$ de lipids.

On the other hand, Tie Su et al. (2013) made a study on hamburgers with concentrations of wet okara up to $25 \%$, found results of $70.00 \%$ moisture, $15.90 \%$ protein and $7.2 \%$ lipids, for this concentration in raw burgers. Hautrive et al. (2008) found $68.11 \%$ moisture, $25.59 \%$ protein and $3.87 \%$ lipids in hamburgers formulated with beef only. Silva et al. (2014) obtained results of $65.47 \%$ moisture, $17.38 \%$ protein and $13.66 \%$ lipids also in hamburgers formulated with just beef. These results corroborate the statement that results vary according to the raw material used, preparation techniques, methods and storage periods.

In spite of the variation found throughout the storage period in the proximate composition, we remark that the formulations are according to the recommended by the Technical Regulations of Identity and Quality of Hamburgers (Brasil, 2000) and they obtained approximate values to those of other authors.

\section{Physical Analyses}

An increase in the instrumental texture of raw hamburgers was noticed with the passing of the storage days, mainly after 60 days, remarking that in all formulations, on the $120^{\text {th }}$ day the texture was higher and different from at all other times (Figure 4A). The first 60 storage days did not influence the change of texture in relation to the control in all the treatments. As the amount of okara added varied, there was a decrease in the results for texture up to the $30^{\text {th }}$ day. From then on, there was not difference between the highest percentage of okara added (F5) and F0.

Regarding the fried hamburgers (Figure 4B), it was noticed that the highest means in texture were at day 120 . It is emphasized that F0, F1, F2 and F4 presented similar behavior up to the $90^{\text {th }}$ day, maintaining their texture means. Formulations F3 and F5 presented a different behavior, with intermediate values from the $60^{\text {th }}$ and the $30^{\text {th }}$ day on respectively.

Concerning the percentage of okara in the formulations, we notice a decrease in the average texture values at times 0,30 and 120 days. At the rest of the times $\left(60^{\text {th }}\right.$ and $90^{\text {th }}$ days) there was no difference between the formulations. So, it is perceived that the highest percentage of okara at the beginning of the storage period confers marked tenderness, but as time passes it matches up with the other treatments, showing to be tenderer (fried) than the control formulation, or similar to it (raw) at the end of the storage period. This fact may suggest some superiority of the formulations containing okara, perhaps due to higher amount of lipids in the formulations containing higher concentrations of okara. The addition of oil in the process of frying may have contributed to greater tenderness of the fried samples in comparison to the raw ones.

The texture of meats is usually altered due to the application of heat on the conjunctive tissue, soluble and myofibrillar proteins. For products made of minced meat, as it is the case of hamburgers, the attributes of texture are deeply related to the functionality of muscle proteins. Their properties of gel formation and emulsification are influenced by the presence of non carneous products (Coggins, 2007), which demonstrates that the presence of wet okara as non carneous products favoured the texture of fried hamburgers. In the case of raw hamburgers, this fact occurs until the $30^{\text {th }}$ day, and from then on, including okara turns the formulation similar to the control.

The results for colour $\left(\mathrm{L}^{*}, \mathrm{a}^{*}, \mathrm{~b}^{*}, \mathrm{C}^{*}\right.$ and $\left.h^{\circ}\right)$ of the raw and fried beef hamburger with addition of okara along the storage period are shown in Table 2.

Luminosity increased as okara was added, in all periods of time and both raw and fried treatments, which indicates higher whiteness of the hamburgers. It is remarkable that the values of lipids were also increased with the inclusion of okara, which may have contributed to the alteration of the colour. Tie Su et al. (2013) report that the creamy colour of okara, similar to that of fat from beef, contributes to lower luminosity in the formulations without okara. Bastos et al. (2014) found similar results when they were researching hamburgers containing fat substitutes. Luminosity decreased along the storage period in all treatments, except for fried $\mathrm{F} 1$ and $\mathrm{F} 2$ where there was no difference during the storage period.

In regard to the values of $a^{*}$ in the raw formulations, we notice that there was no difference at the beginning of the storage period when comparing to the final deadline of 120 days, except for F0, which was different statistically. As for the fried formulations an increase in the values of $\mathrm{a}^{*}$ was observed on the $120^{\text {th }}$ day when compared to day 0 , turning the hamburgers less reddish, with exception again for F0. 

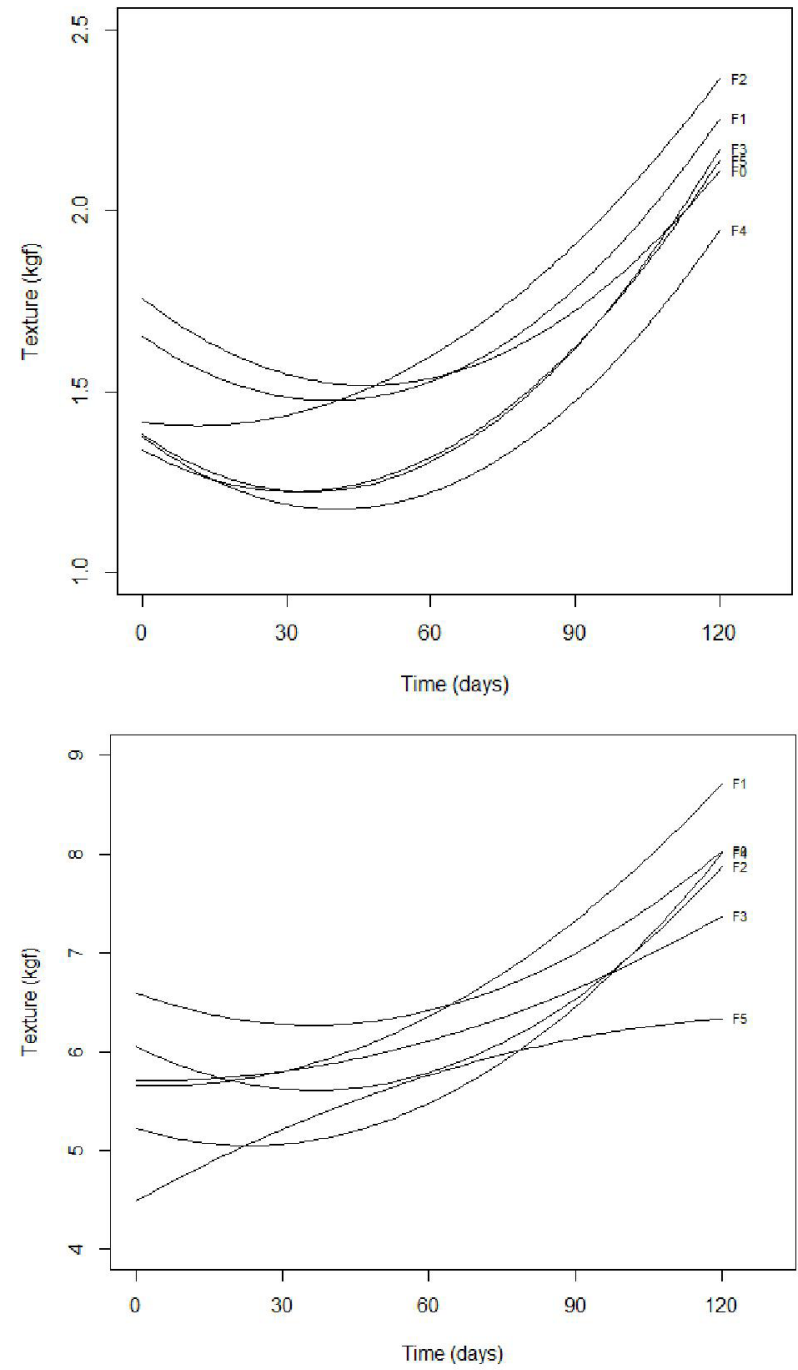

A

F0- $y=1,75-0,01 x+0,0001 x^{2} R^{2}=97 \%$

$\mathrm{F} 1-\mathrm{y}=1,65-0,009 \mathrm{x}+0,0001 \mathrm{x}^{2} \mathrm{R}^{2}=99 \%$

F2- $y=1,41-0,002+0,00008 x^{2} R^{2}=96 \%$

F3- $y=1,38-0,009 x+0,0001 x^{2} R^{2}=99 \%$

F4- $y=1,37-0,009 x+0,0001 x^{2} R^{2}=99 \%$

F5- $y=1,33-0,007 x+0,0001 x^{2} R^{2}=99 \%$
F0 - y $=6,59-0,01 x+0,0002 x^{2} R^{2}=84 \%$ $F 1-y=5,66-0,002 x+0,0002 x^{2} R^{2}=96 \%$ F2- $y=6,05-0,02 x+0,0003 x^{2} R^{2}=85 \%$ F3- $y=5,70-0,0004 x+0,0001 x^{2} R^{2}=97 \%$ F4- $y=5,22-0,01 x+0,0003 x^{2} R^{2}=93 \%$ F5- $y=4,49+0,02 x-0,00009 x^{2} R^{2}=92 \%$

Figure 4: Means observed, and regression model adjusted for protein values (\%) of raw (A) and fried (B) beef hamburgers with addition of different concentrations of wet okara along the storage period in days. F0- control; F1- 5\%; F2- 10\%; F3- 15\%; F4- 20\%; F5- 25\%.

The red colour is mostly given to meat products by myoglobin and cytochrome $\mathrm{C}$, heme pigments naturally present in meat (Beriain et al., 2009). It is expected that the higher their amount, the higher the content of red (Karamucki et al., 2013). It is highlighted that in the raw formulations with addition of okara (which would not provide these pigments, and on the contrary, it would promote their reduction) the formulations maintained the colour. Regarding the fried formulations with addition of okara, the decrease of the red colour is noticed after the beginning of the storage period.
In parameter $b^{*}$ it is noticed that among the raw formulations F0 presented its highest value at the $120^{\text {th }}$ day and the lowest value at time zero, with days 30, 60 and 90 similar among each other, and different from the rest. In F1 the lowest value was observed at time zero, being different at the others times. For F2 the lowest value was observed at time zero, and this was equal on days 60 and 90. F3, F4 and F5 did not show any difference between moment zero and the $120^{\text {th }}$ day of storage. As the storage time passed, it was noticed that the inclusion of okara did not influence the increase in the values of $b^{*}$. In the formulations F0 up to F2, the 
increase of these values was observed with the passing of time, with these formulations containing more meat and being more susceptible to alterations in the brown colouring given by myoglobin.
In relation to the parameter $b^{*}$ of fried hamburgers it was noticed that in all formulations at the $120^{\text {th }}$ day the values were higher and statistically different from time zero, which indicates the maintenance of the colour.

Table 2: Parameters $L^{*}, a^{*}, b^{*}, C^{*}$ e ho of formulations of raw and fried beef hamburgers with addition of wet okara in different concentrations throughout their storage period in days.

\begin{tabular}{|c|c|c|c|c|c|c|c|c|c|c|c|}
\hline \multicolumn{2}{|c|}{ Parâmeter Okara(\%) } & \multirow{2}{*}{$\begin{array}{c}\text { TOC } \\
58.32^{\mathrm{aE}}\end{array}$} & \multirow{2}{*}{$\begin{array}{c}\text { TOF } \\
54.29^{\mathrm{aD}}\end{array}$} & \multirow{2}{*}{$\begin{array}{c}\mathrm{T} 30 \mathrm{C} \\
52.16^{\mathrm{cdE}}\end{array}$} & \multirow{2}{*}{$\frac{\mathrm{T} 30 \mathrm{~F}}{50.25^{\mathrm{abc}}}$} & \multirow{2}{*}{$\begin{array}{c}\mathrm{T} 60 \mathrm{C} \\
51.70^{\mathrm{dD}}\end{array}$} & \multirow{2}{*}{$\begin{array}{c}\text { T60F } \\
48.39^{\mathrm{bc}}\end{array}$} & \multirow{2}{*}{$\frac{\mathrm{T} 90 \mathrm{C}}{53.92^{\mathrm{bCD}}}$} & \multirow{2}{*}{$\begin{array}{c}\text { T90F } \\
50.21^{\mathrm{abc}}\end{array}$} & \multirow{2}{*}{$\begin{array}{r}\mathrm{T} 120 \mathrm{C} \\
55.72^{\mathrm{bD}}\end{array}$} & \multirow{2}{*}{$\frac{\mathrm{T} 120 \mathrm{~F}}{46.0 \mathrm{~g}^{\mathrm{BB}}}$} \\
\hline$L^{*}$ & F0 & & & & & & & & & & \\
\hline & F1 & $62.76^{\mathrm{ad}}$ & $58.27^{\mathrm{aCD}}$ & $57.95^{\mathrm{bD}}$ & $58.12^{a \mathrm{~B}}$ & $58.25^{b c}$ & $57.46^{\mathrm{aB}}$ & $57.83^{\mathrm{bc}}$ & $57.09^{a b}$ & $58.55^{\mathrm{bc}}$ & $56.76^{\mathrm{aA}}$ \\
\hline & F2 & $65.41^{\mathrm{ac}}$ & $58.84^{\mathrm{aBCD}}$ & $61.16^{\mathrm{bc}}$ & $60.29^{a \mathrm{~B}}$ & $60.93^{\mathrm{bB}}$ & $59.94^{\mathrm{aAB}}$ & $59.85^{\mathrm{bBC}}$ & $57.76^{\mathrm{aB}}$ & $61.04^{\mathrm{bB}}$ & $55.69^{\mathrm{aA}}$ \\
\hline & F3 & $67.80^{\mathrm{aB}}$ & $61.81^{\mathrm{aABC}}$ & $65.68^{\mathrm{bB}}$ & $59.00^{\mathrm{abB}}$ & $62.55^{\mathrm{cB}}$ & $55.68^{\mathrm{bcB}}$ & $61.11^{\mathrm{CB}}$ & $59.69^{\mathrm{abAB}}$ & $61.10^{\mathrm{CB}}$ & $53.92^{\mathrm{cA}}$ \\
\hline & F4 & $67.69^{a B}$ & $64.29^{\mathrm{aA}}$ & $62.63^{b c}$ & $59.54^{\mathrm{bcB}}$ & $61.15^{\mathrm{bcB}}$ & $62.81^{\mathrm{abA}}$ & $60.08^{\mathrm{cB}}$ & $57.24^{\mathrm{CB}}$ & $61.15^{\mathrm{bcB}}$ & $57.61^{\mathrm{CA}}$ \\
\hline & F5 & $71.59^{\mathrm{aA}}$ & $63.65^{\mathrm{aAB}}$ & $69.86^{\mathrm{aA}}$ & $66.56^{\mathrm{aA}}$ & $67.34^{\mathrm{bA}}$ & $64.25^{\mathrm{aA}}$ & $66.89^{\mathrm{bA}}$ & $63.62^{\mathrm{aA}}$ & $67.77^{\mathrm{bA}}$ & $56.83^{\mathrm{bA}}$ \\
\hline & F0 & $2.13^{\mathrm{aAB}}$ & $4.57^{\mathrm{abAB}}$ & $2.55^{\mathrm{aA}}$ & $2.92^{\mathrm{bD}}$ & $2.13^{\mathrm{bAB}}$ & $5.18^{\mathrm{aAB}}$ & $1.29^{c c}$ & $2.87^{\mathrm{bc}}$ & $1.94^{\text {bВ }}$ & $6.20^{\mathrm{aB}}$ \\
\hline \multirow[t]{5}{*}{$a^{*}$} & $\mathrm{~F} 1$ & $1.81^{\mathrm{abB}}$ & $4.58^{\mathrm{bAB}}$ & $2.13^{\mathrm{aB}}$ & $3.82^{\mathrm{bc}}$ & $1.48^{\mathrm{bc}}$ & $4.80^{\mathrm{abB}}$ & $1.96^{\mathrm{aB}}$ & $3.87^{\mathrm{bBC}}$ & $1.92^{\mathrm{aB}}$ & $6.55^{\mathrm{aB}}$ \\
\hline & F2 & $2.26^{\mathrm{abA}}$ & $4.51^{\mathrm{bcB}}$ & $2.43^{\mathrm{aAB}}$ & $6.22^{\mathrm{abB}}$ & $1.97^{\mathrm{ab} A \mathrm{~B}}$ & $5.04^{\mathrm{abB}}$ & $2.56^{\mathrm{aA}}$ & $3.13^{\mathrm{CBC}}$ & $2.51^{\mathrm{aA}}$ & $6.75^{\mathrm{aB}}$ \\
\hline & F3 & $2.32^{\mathrm{aA}}$ & $5.41^{\mathrm{bCAB}}$ & $2.06^{\mathrm{abB}}$ & $4.63^{\mathrm{CBCD}}$ & $1.78^{\mathrm{bBC}}$ & $7.00^{\mathrm{abA}}$ & $2.08^{\mathrm{abB}}$ & $4.57^{\mathrm{CBC}}$ & $2.16^{\mathrm{aAB}}$ & $8.00^{\mathrm{aAB}}$ \\
\hline & F4 & $2.36^{\mathrm{bA}}$ & $4.45^{\mathrm{cB}}$ & $2.72^{\mathrm{aA}}$ & $8.82^{\mathrm{aA}}$ & $2.10^{\mathrm{bAB}}$ & $6.04^{\mathrm{bcAB}}$ & $2.21^{\mathrm{bAB}}$ & $7.69^{\mathrm{abA}}$ & $2.11^{\mathrm{bB}}$ & $7.89^{\mathrm{aAB}}$ \\
\hline & F5 & $2.44^{\mathrm{abA}}$ & $6.43^{\mathrm{bA}}$ & $2.64^{\mathrm{aA}}$ & $5.42^{\mathrm{bBC}}$ & $2.25^{\mathrm{bA}}$ & $6.18^{\mathrm{bAB}}$ & $2.30^{\mathrm{ab} A \mathrm{~B}}$ & $4.83^{\text {bв }}$ & $2.20^{\mathrm{bAB}}$ & $9.11^{\mathrm{aA}}$ \\
\hline \multirow[t]{7}{*}{$b^{*}$} & F0 & $8.75^{c c}$ & $13.57^{\mathrm{bD}}$ & $12.55^{\mathrm{bCD}}$ & $9.53^{\mathrm{CD}}$ & $11.61^{b c}$ & $10.72^{\mathrm{CD}}$ & $12.49^{b c}$ & $10.57^{\mathrm{CD}}$ & $14.68^{\mathrm{aA}}$ & $19.05^{\mathrm{ac}}$ \\
\hline & $\mathrm{F} 1$ & $9.82^{c c}$ & $16.95^{b c}$ & $11.65^{\mathrm{bD}}$ & $15.22^{b c}$ & $13.45^{\mathrm{aAB}}$ & $15.98^{\mathrm{bc}}$ & $13.35^{\mathrm{aBC}}$ & $15.37^{b c}$ & $12.55^{\mathrm{abB}}$ & $26.63^{\mathrm{aA}}$ \\
\hline & $\mathrm{F} 2$ & $12.02^{\text {св }}$ & $16.96^{c c}$ & 13.9 & $20.48^{\mathrm{bAB}}$ & $12.39^{\mathrm{bcBC}}$ & $18.16^{\mathrm{bcBC}}$ & $13.08^{\mathrm{abcBC}}$ & $15.83^{\mathrm{cBC}}$ & $13.59^{\mathrm{abAB}}$ & $23.07^{\mathrm{aB}}$ \\
\hline & F3 & $13.88^{\mathrm{abA}}$ & $20.00^{\mathrm{bAB}}$ & $15.04^{\mathrm{aAB}}$ & $17.97^{\mathrm{bB}}$ & $13.29^{\mathrm{bAB}}$ & $19.79^{\mathrm{bAB}}$ & $14.33^{\mathrm{ab} A B}$ & $18.19^{\mathrm{bAB}}$ & $14.20^{\mathrm{abA}}$ & $26.43^{\mathrm{aA}}$ \\
\hline & F4 & $13.66^{\mathrm{bcA}}$ & $18.25^{\mathrm{dBC}}$ & $15.44^{\mathrm{aAB}}$ & $22.46^{\mathrm{bA}}$ & $12.72^{\mathrm{CABC}}$ & $21.39^{\mathrm{bcA}}$ & $14.31^{\mathrm{abAB}}$ & $19.78^{\mathrm{cdA} A}$ & $13.77^{\mathrm{bcAB}}$ & $26.72^{\mathrm{aA}}$ \\
\hline & F5 & $14.23^{\mathrm{bA}}$ & $21.44^{\mathrm{bA}}$ & $16.54^{\mathrm{aA}}$ & $22.23^{\mathrm{bA}}$ & $14.20^{\mathrm{bA}}$ & $22.09^{\mathrm{bA}}$ & $15.05^{\mathrm{bA}}$ & $20.37^{\mathrm{bA}}$ & $14.77^{\mathrm{bA}}$ & $28.55^{\mathrm{aA}}$ \\
\hline & F0 & $9.01^{c c}$ & $14.33^{\mathrm{bD}}$ & $12.81^{\mathrm{bDE}}$ & $9.97^{\mathrm{CD}}$ & $11.80^{\mathrm{bc}}$ & $11.67^{\mathrm{bcD}}$ & $12.58^{b c}$ & $10.53^{c c}$ & $14.81^{\mathrm{aA}}$ & $20.05^{\mathrm{aD}}$ \\
\hline \multirow[t]{6}{*}{$c^{*}$} & $\mathrm{~F} 1$ & $9.99^{c c}$ & $17.57^{a c}$ & $11.85^{\mathrm{bE}}$ & $15.69^{a c}$ & $13.53^{\mathrm{aAB}}$ & $16.68^{\mathrm{ac}}$ & $13.50^{\mathrm{aBC}}$ & $15.80^{\mathrm{aB}}$ & $12.71^{\mathrm{abB}}$ & $26.46^{\mathrm{bBC}}$ \\
\hline & $\mathrm{F} 2$ & $12.24^{\mathrm{CB}}$ & $17.87^{\mathrm{CBC}}$ & $14.15^{\mathrm{aCD}}$ & $21.28^{\mathrm{ab} A B}$ & $12.54^{\mathrm{bcBC}}$ & $18.83^{\mathrm{bcBC}}$ & $13.33^{\mathrm{abcBC}}$ & $14.15^{\mathrm{dB}}$ & $13.83^{\mathrm{abAB}}$ & $23.87^{a c}$ \\
\hline & F3 & $14.07^{\mathrm{abA}}$ & $20.73^{\mathrm{bAB}}$ & $15.18^{\mathrm{aBC}}$ & $18.69^{\mathrm{bA}}$ & $13.41^{\mathrm{bAB}}$ & $20.89^{\mathrm{bAB}}$ & $14.48^{\mathrm{abAB}}$ & $19.93^{\mathrm{bA}}$ & $14.36^{\mathrm{abA}}$ & $27.63^{\mathrm{aAB}}$ \\
\hline & F4 & $13.87^{\mathrm{bcA}}$ & $19.58^{\mathrm{CABC}}$ & $15.68^{\mathrm{aAB}}$ & $24.13^{\mathrm{bA}}$ & $12.89^{\mathrm{CABC}}$ & $22.14^{\mathrm{bcA}}$ & $14.80^{\mathrm{abAB}}$ & $20.52^{\mathrm{cA}}$ & $13.93^{\mathrm{bcAB}}$ & $27.88^{\mathrm{aAB}}$ \\
\hline & F5 & $14.43^{\mathrm{bA}}$ & $22.22^{\mathrm{bA}}$ & $16.75^{\mathrm{aA}}$ & $23.01^{\mathrm{bA}}$ & $14.37^{\mathrm{bA}}$ & $22.87^{\mathrm{bA}}$ & $15.22^{\mathrm{bA}}$ & $21.12^{\mathrm{bA}}$ & $14.93^{\mathrm{bA}}$ & $29.97^{\mathrm{aA}}$ \\
\hline & F0 & $69.63^{с в}$ & $71.45^{\mathrm{aA}}$ & $78.49^{\mathrm{bA}}$ & $72.96^{\mathrm{AA}}$ & $79.53^{\mathrm{abA}}$ & $64.56^{b c}$ & $83.36^{\mathrm{AA}}$ & $73.21^{\mathrm{aAB}}$ & $82.43^{\mathrm{abA}}$ & $72.06^{\mathrm{aA}}$ \\
\hline \multirow[t]{5}{*}{$h^{*}$} & $\mathrm{~F} 1$ & $79.52^{\mathrm{aA}}$ & $74.82^{\mathrm{aA}}$ & $79.60^{\mathrm{aA}}$ & $75.93^{\mathrm{aA}}$ & $83.70^{\mathrm{aA}}$ & $73.62^{\mathrm{aAB}}$ & $81.63^{\mathrm{aA}}$ & $77.70^{\mathrm{aA}}$ & $81.28^{\mathrm{aA}}$ & $75.75^{\mathrm{aA}}$ \\
\hline & F2 & $79.29^{\mathrm{aA}}$ & $75.41^{\mathrm{aA}}$ & $80.12^{\mathrm{aA}}$ & $73.45^{\mathrm{AA}}$ & $80.95^{\mathrm{aA}}$ & $75.02^{\mathrm{aA}}$ & $78.89^{\mathrm{aA}}$ & $78.23^{\mathrm{aA}}$ & $79.54^{\mathrm{aA}}$ & $75.31^{\mathrm{aA}}$ \\
\hline & F3 & $80.50^{2 \mathrm{~A}}$ & $74.86^{\mathrm{aA}}$ & $82.19^{\mathrm{aA}}$ & $74.97^{\mathrm{AA}}$ & $82.38^{\mathrm{aA}}$ & $69.77^{\mathrm{bB}}$ & $81.72^{\mathrm{aA}}$ & $75.76^{\mathrm{AA}}$ & $80.99^{a A}$ & $73.21^{\mathrm{abA}}$ \\
\hline & F4 & $80.13^{\mathrm{aA}}$ & $76.03^{\mathrm{aA}}$ & $79.98^{\mathrm{aA}}$ & $65.25^{\mathrm{CB}}$ & $80.59^{a A}$ & $75.76^{\mathrm{aA}}$ & $81.39^{\mathrm{aA}}$ & $69.92^{\mathrm{bcB}}$ & $81.29^{\mathrm{aA}}$ & $73.73^{\mathrm{abA}}$ \\
\hline & F5 & $80.26^{\mathrm{aA}}$ & $74.96^{\mathrm{aA}}$ & $80.93^{\mathrm{aA}}$ & $75.80^{\mathrm{aA}}$ & $81.00^{\mathrm{aA}}$ & $74.18^{\mathrm{aAB}}$ & $81.29^{\mathrm{aA}}$ & $75.65^{\mathrm{AA}}$ & $81.50^{\mathrm{aA}}$ & $72.29^{\mathrm{aA}}$ \\
\hline
\end{tabular}

Means followed by the same letter on the same line and column of each formulation do not differ significantly, with $5 \%$ probability, by Tukey's test. Lower case letters represent the analysis along the time and capital letters represent it between formulations. TOC $=$ day 0 raw, TOF $=$ day 0 fried, $T 30 \mathrm{C}=30^{\text {th }}$ day raw, T30F $=30^{\text {th }}$ day fried, $\mathrm{T} 60 \mathrm{C}=60^{\text {th }}$ day raw, T60F $=60^{\text {th }}$ day fried, $\mathrm{T} 90 \mathrm{C}=90^{\text {th }}$ day raw, $\mathrm{T} 90 \mathrm{~F}=90^{\text {th }}$ day fried, $\mathrm{T} 120 \mathrm{C}=120^{\text {th }}$ day raw, $\mathrm{T} 120 \mathrm{~F}=120^{\text {th }}$ day fried. 
The values of chromaticity for raw and fried hamburgers were higher according to the inclusion of okara, with all F5s higher and different from F0s. The same behavior was seen along the storage period, noticing that the freezing turned the brown colour more intense all the hamburgers.

The calculation of the values of the Hue angle for the raw hamburgers showed difference in just $\mathrm{F} 0$ during the 120day storage period. About the fried hamburgers, there was no difference in any of the formulations between time zero and the $120^{\text {th }}$ day. According to Ordoñez (2005) the processing of meat parts and their byproducts causes changes in their colour. Freezing favours the brownish tonality of meats by the difficulty of the penetration of $\mathrm{O}_{2}$, and for having electrolites that favour metmyoglobin (grayish brown colour).

In Figure 5 is observed the colour corresponding to the coordenates $\mathrm{L}^{*}, \mathrm{a}^{*}$ and $\mathrm{b}^{*}$ through a dispersion diagram in three dimentions for the raw and fried hamburgers, at time zero and 120 days of storage period, respectively. The colour of each treatment is represented by one dot. For the raw formulations at time zero, lower values of $a^{*}$ and $b^{*}$ are observed when compared to time zero in fried hamburgers, which take a light brown colour, indicating the clearing the colour by the increase in the addition of okara. The fried hamburgers also have this indication, but they present a darker brown tonality.
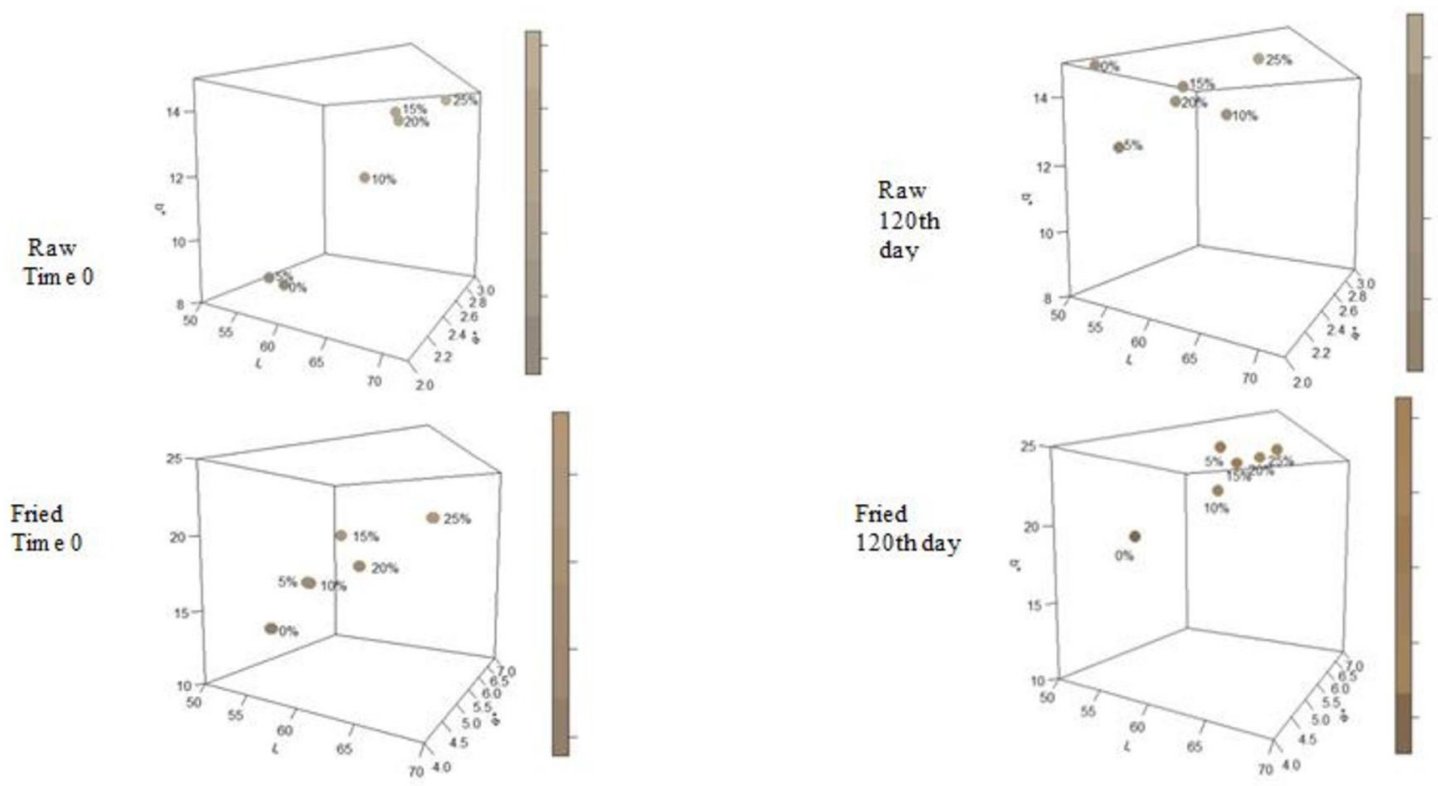

Figure 5: Diagram of dispersion in 3D (RGB - red-green-blue system) of the formulations of raw and fried beef hamburger with addition of wet okara (\%) on days 0 and 120 of storage. 


\section{CONCLUSIONS}

It can be concluded after 120 days storage the levels of protein, lipid and moisture of the formulations were according to the recommended by the Technical Regulation for Identity and Quality of Hamburgers and comply with the requirements of the Brazilian Law for microbiological standards. The brown colour changed with the inclusion of okara but without alterations in the characteristic colour for beef burguers.

\section{ACKNOWLEDGEMENTS}

The author thank: Capes, CNPq, and FAPEMIG for the financial support; UNIFENAS-MG (Laboratory of Biology and Physiology of Microorganisms), UNIFALMG (Nutrition College) and UFLA (Department of Food Science) for the constant support.

\section{REFERENCES}

AKWETEY, W. Y.; KNIPE, C. Sensory attributes and texture profile of beef burgers with gari. Meat Science. 92(4):745748, 2012.

ASSOCIATION OF OFFICIAL ANALYTICAL CHEMISTS - AOAC. Official Method of Analysis. 18.ed. Washington, DC, USA, 2005.

APLEVICZ, K. S.; DEMIATE, I. M. Physicochemical analyses of commercial samples of cheese bread premix and production of cheese breads with addition of okara. Ciência e Agrotecnologia. 31(5):1416-1422, 2007.

BASTOS, S. C. et al. Alternative fat substitutes for beef burger: Technological and sensory characteristics. Journal of Food Science and Technology. 51(9):20462053, 2014.

BERIAIN, M. J. et al. Predicting Longissimus dorsi myoglobin oxidation in aged beef based on early post-mortem colour measurements on the carcass as a colour stability index. Meat Science. 81(3):439-445, 2009.

BOWLES, S.; DEMIATE, I. M. Physicochemical characterization of the soymilk by product - okara. Food Science and Technology. 26(3):652-659, 2006.

BRASIL. Ministério da Agricultura e do Abastecimento. Instrução Normativa $n^{\circ} 20$, de 31 de janeiro de 2000. Regulamento Técnico de Identidade e Qualidade de Hamburguer. Brasília: Ministério da Agricultura e do Abastecimento, 2000. Available in: <http://www.cfmv.org.br/portal/ legislacao/outras_normas/instrucao_normativa_020_MAA. htm>. Access in: September, 1, 2015.
BRASIL, Ministério da Saúde, Agência Nacional de Vigilância Sanitária (ANVISA), Resolução RDC n 12 de 02 de janeiro de 2001. Regulamento Técnico Sobre Os Padrões Microbiológicos para Alimentos. Diário Oficial. Brasília, DF. Available in: <http://portal.anvisa.gov.br/wps/ wcm/connect/a47bab8047458b909541d53fbc4c6735/ RDC_12_2001.pdf?MOD=AJPERES>. Access in: September, 28, 2015.

COGGINS, P. C. Attributes of muscle foods: Color, texture, flavour. Handbook of Meat, poultry and Seafood Quality. Second Edition. lowa: Blackwell Publishing, pp 89-97, 2007.

FERREIRA, E. B.; CAVALCANTI, P. P.; NOGUEIRA, D. A. ExpDes: An $R$ package for ANOVA and experimental designs. Applied Mathematics. 5:2952-2958, 2014.

GESINDE, A. F.; OYAWOYE, O. M.; ADEBISI, A. Comparative studies on the quality and quantity of soymilk from different varieties of soybean. Pakistan Journal of Nutrition. 7(1):157-160, 2008.

HAUTRIVE, T. P. et al. Physicochemical and sensorial analyses of ostrich hamburger. Food Science and Technology. 28:95-101, 2008.

JIMÉNEZ-ESCRIG, A.; SERRA, M. T.; RUPÉREZ, P. Non-digestible carbohydrates in Brazilian soybean seeds [Glycine max (L.) Merril]. International Journal of Food Science and Technology. 45:2524-2530, 2010.

KARAMUCKI, T. et al. The influence of myoglobin on the colour of minced pork loin. Meat Science. 94(2):234-238, 2013.

MATEOS-APARICIO, I.; REDONDO-CUENCA, A.; VILLANUEVASUÁREZ, M. J. Isolation and characterization of cell wall polysaccharides from legume by-products: Okara (soymilk residue), pea pod and broad bean pod. Food Chemistry. 122(1):339-345, 2010.

NASCIMENTO, M. G. F.; OLIVEIRA, C. Z. F.; NASCIMENTO, E. R. Hambúrguer evolução comercial e padrões microbiológicos. Boletim do CEPPA. 23(1):59-74, 2005.

OLIVEIRA, D. F. et al. Alternatives for a healthier meat product: A review. Brazilian Journal of Food Technology. 16(3):163174, 2013.

OLIVEIRA, M. M. et al. Apparent digestibility and digestible energy of some organic residues in food of tilapia. Electronic Journal Nutritime. 5(5):648-657, 2008.

ORDÓÑEZ, J. A. Tecnologia de Alimentos: Componentes dos alimentos e processos. Porto Alegre: Artmed, v.1, 2005. 294p. 
Perussello, C. A.; AMARANTE, A. C. C.; MARIANE, V. C. Convective drying kinetics and darkening of okara. Drying technology. 27(10):1132-1141, 2009.

PIRES, I. S. C. et al . Proximate analysis, weight losses and tenderness of pork loin (longissimus dorsi) submitted to different freezing and thawing treatments. Journal of Nutrition. 15(2):163-172, 2002.

PROVESI, J. G.; AMANTE, E. R. Revisão: Antifreeze proteins - an emerging technology for freezing foods. Brazilian Journal of Food Technology. 18(1):2-13, 2015.

R CORE TEAM. R: A language and environment for statistical computing. R Foundation for Statistical Computing, Vienna, Austria. 2015. Available in: <http://www.R-project.org/> Access in: September, 10, 2015.

RIBEIRO, M. L. L. et al. Isoflavone content and b-glucosidase activity in soybean cultivars of different maturity groups. Journal of Food Composition and Analysis. 20:19-24, 2007.

SENGUPTA, A. et al. Study on the effects of drying process on the composition and quality of wet okara. International Journal of Science, Environment and Technology. 1(4):319-330, 2012.
SILVA, F. L. et al. Physicochemical parameters and sensory acceptance of buffalo burgers as compared to beef burgers. Brazilian Journal of Food Technology. 17(4):340344, 2014.

SILVA, N.; JUNQUEIRA, V. C. A.; SILVEIRA, N. F. A. Manual de Métodos de Análise de Alimentos. 3.ed. São Paulo: Varela, 2007. 544p.

SOETAERT, K. plot3D: Plotting multi-dimensional data. R package version 1.0-2. 2014. Available in: <http://CRAN.Rproject.org/package=plot3D>. Access in: September, 02, 2015.

SOLTANIZADEH, N.; GHIASI-ESFAHANI, H. Qualitative improvement of low meat beef burger using Aloe vera. Meat Science. 99:75-80, 2015.

TIE SU, S. I. et al. Okara, a soymilk industry by-product, as a non-meat protein source in reduced fat beef burgers. Food Science and Technology. 33(1):52$56,2013$.

TURHAN, S.; TEMIZ, H.; SAGIR, I. Characteristics of beef patties using okara powder. Journal of Muscle Foods. 20:89-100, 2009. 